\title{
Cooling Effect of Crushed Rock-Based Embankment along the Chaidaer-Muli Railway
}

\author{
Ji Chen, ${ }^{1}$ Yu Sheng, ${ }^{1}$ Yaling Chou, ${ }^{2}$ Lei Liu, ${ }^{3}$ and Bo Zhang ${ }^{4}$ \\ ${ }^{1}$ State Key Laboratory of Frozen Soil Engineering, Cold and Arid Regions Environmental and Engineering Research Institute, \\ Lanzhou 730000, China \\ ${ }^{2}$ College of Civil Engineering, Lanzhou University of Technology, Lanzhou 730050, China \\ ${ }^{3}$ Qinghai Research Institute of Transportation Science and Technology, Xining 810000, China \\ ${ }^{4}$ China Railway First Survey \& Design Institute Group Co., Ltd., Xian 710043, China \\ Correspondence should be addressed to Ji Chen; chenji@lzb.ac.cn
}

Received 1 May 2015; Revised 20 July 2015; Accepted 28 July 2015

Academic Editor: Bert Blocken

Copyright (C) 2015 Ji Chen et al. This is an open access article distributed under the Creative Commons Attribution License, which permits unrestricted use, distribution, and reproduction in any medium, provided the original work is properly cited.

This paper presents an experimental study of the cooling effect of crushed rock-based embankment on slope wetlands along the Chaidaer-Muli Railway. The result shows that only the embankment shady side can be effectively cooled down in a warm permafrost region and the crushed rock-based embankment can cool the entire embankment in a cold permafrost region. The crushed rockbased embankment cannot eliminate the problems from the south-north slope. Slope wetland can influence the temperature field of the crushed rock-based embankment. On the uphill side, it will lead to degradation in some cases and development of permafrost in other cases, which depends on the topsoil water content and ground surface runoff. On the downhill side, it always leads to the warming of permafrost. For crushed rock-based embankment constructed on slope wetlands, it is necessary to adopt other stronger measures to eliminate the sunny-shady slope problems.

\section{Introduction}

The crushed rock-based embankment can provide active protection for permafrost and has been widely used in the construction of railways in permafrost regions. In the former Soviet Union, the crushed rock-based embankment was studied since the 1960s. Crushed rock was adopted as the roadbed filler to maintain the permafrost table along the Baikal-Amur Mainline and good results were achieved [1]. In the 1960s, 1970s, and 1980s, experimental studies on the crushed rock-based embankment were also carried out in Fenghuoshan Mountain, Rehui coal mine, and Heilongjiang Province in China [2-4]. Field data revealed that equivalent coefficient of heat conductivity of the crushed rock-based embankment in winter is approximately $5-10$ times that in the summer $[5,6]$. Mean annual ground temperature (MAGT) under the crushed rock-based embankment is much lower than that under the ordinary embankment [2]. After the year 2000 , crushed rock-based embankments have been adopted in many highway and railway engineering. There are $130 \mathrm{~km}$ crushed rock-based embankments for Qinghai-Tibet Railway and $72 \mathrm{~km}$ for Gonghe-Yushu expressway [7, 8].

To study the heat-transfer mechanisms, engineering effects, and crushed rock-based embankment design parameters, Goering et al. [9-12] performed extensive studies on the crushed rock cooling mechanism and related technical problems based on a combination of model tests, numerical simulations, and field experiments. His study revealed that crushed rock-based embankment reduces the amount of heat absorbed by the underlying permafrost from the atmosphere in the summer and increases heat releases in winter. Lai et al. [13] established numerical models with the assumption that the air temperature would increase by $2.0^{\circ} \mathrm{C}$ over 50 years to analyze how the permafrost temperature will change under the traditional ballast embankment and the crushed rockbased embankment. The results showed that the crushed rock-based embankment can provide a good cooling effect to the permafrost. 
TABLE 1: The geographic, geologic, and engineering characteristics of the monitoring section of crushed rock-based embankment.

\begin{tabular}{|c|c|c|c|c|c|c|c|}
\hline Geomorphic unit & Milestone & $\mathrm{EH} / \mathrm{m}$ & $\mathrm{PT} / \mathrm{m}$ & $\mathrm{SG} /^{\circ}$ & Strike $^{\circ}$ & $\mathrm{MAGT} /{ }^{\circ} \mathrm{C}$ & Ice features \\
\hline Northern slope of Datong Mountain & $\mathrm{DK} 40+000$ & 6.0 & 1.0 & $<5$ & 320 & -0.65 & Ice-saturated \\
\hline North bank of Datong river & DK74+000 & 8.0 & 1.0 & $<5$ & 300 & -0.55 & Ice-rich \\
\hline North bank of Xuzhigequ river & DK94+900 & 4.5 & 1.3 & 7 & 345 & -1.31 & Ice-saturated \\
\hline North bank of Duosuoqu river & $\mathrm{DK} 123+150$ & 4.5 & 1.4 & 3 & 260 & -1.18 & Ice-saturated \\
\hline North bank of Duosuoqu river & DK123+250 & 4.5 & 1.0 & 3 & 260 & -1.18 & Ice-saturated \\
\hline
\end{tabular}

Notes: EH: embankment height, PT: permafrost table, SG: slope gradient, and MAGT: mean annual ground temperature.

Although many simulation and experimental results indicate that the crushed rock-based embankment has played positive roles in cooling the underlying permafrost, some researchers have questioned its wide application. Through field investigations, Wu et al. [14] showed that there is better thermal stability when the temperature near the permafrost table under the crushed rock-based embankment decreases greatly in cold permafrost regions. But, in warm permafrost regions, thermal balance of permafrost will be disturbed, and it is disadvantageous to the stability of frozen soil embankment. Therefore, it is worth discussing the applicability of the crushed rock-based embankment under different permafrost conditions including the MAGT and ice content. About $53 \mathrm{~km}$ crushed rock-based embankments are used along the Chaidaer-Muli Railway (CMR) in both cold and warm permafrost regions. Moreover, the railway extends from southeast to northwest and mainly runs across slope wetlands. The embankment sections are asymmetric and the sunny-shady slope phenomenon cannot be neglected. Therefore, the engineering effect of the crushed rock-based embankment becomes more complex in the CMR.

\section{Materials and Methods}

2.1. Site Description. The CMR is the first local railway of Qinghai Province, China, located in the north of the QinghaiTibet Plateau and in the central part of the Qilian Mountains (Figure 1). It extends $142 \mathrm{~km}$ from the Reshui coal mine to the town of Muli. The elevations along the railway range from $3600 \mathrm{~m}$ to $4100 \mathrm{~m}$. According to the meteorological data of the past several years, the minimum and maximum air temperatures are $-40^{\circ} \mathrm{C}$ and $17^{\circ} \mathrm{C}$, respectively. The annual precipitation is approximately $500 \mathrm{~mm}$. The railway traverses slope wetland, where the freezing and thawing grass hummocks are fully developed and the vegetation fraction is generally more than $90 \%$ (Figure $2(\mathrm{c})$ ). The permafrost is discontinuous and unstable with an MAGT range of approximately $-1.5^{\circ} \mathrm{C}$ to $0^{\circ} \mathrm{C}$. The ice content in most permafrost regions is generally relatively high.

Previous studies found that cooling effect of crushed rock-based embankment may be influenced by the MAGT. In some warm permafrost area, cooling effect of crushed rock-based embankment is not significant [15]. MAGTs of permafrost along the CMR vary from $0^{\circ} \mathrm{C}$ to $-1.5^{\circ} \mathrm{C}$. The "Design Rules of the Qinghai-Tibet Railway" pointed out that the critical temperature between warm and cold permafrost is $-1.0^{\circ} \mathrm{C}$. Based on this standard, five monitoring sections

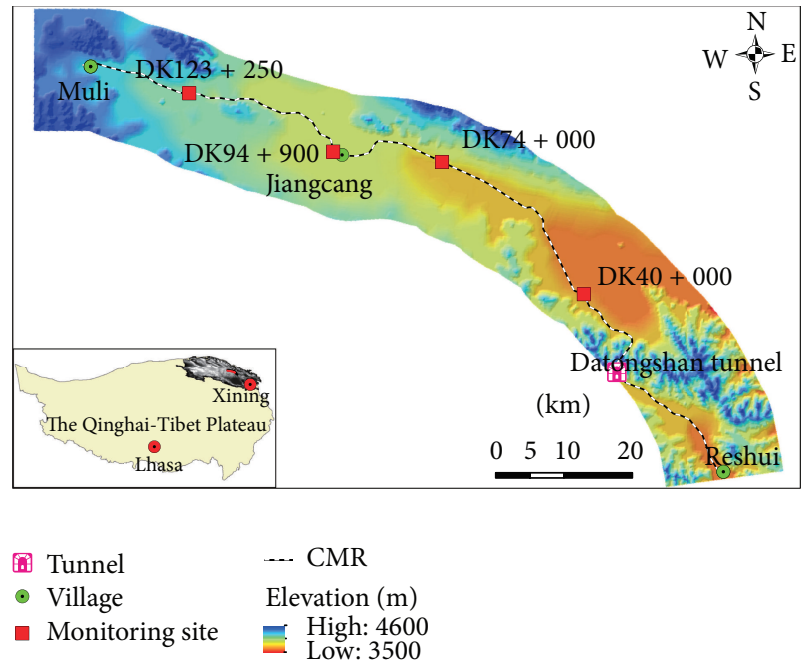

FIgURE 1: Location of the CMR in the Qilian Mountains and Qinghai-Tibet Plateau.

were chosen to learn the cooling effect of crushed rockbased embankment along the CMR (Table 1). Sections of the DK40+000 and DK74+000 are located in the warm permafrost zone, and the other three sections are located in the cold permafrost zone. All the five sections are all located on wetland with gentle slope, where the ice content is very high. A section of DK40+000 is in a northward mountain slope and the other four sections are in a southward mountain slope. The geographic, geologic, and engineering characteristics of the monitoring sections are listed in Table 1 . The embankment height refers to the central height of the embankment because most embankment sections are asymmetric.

\subsection{Crushed Rock-Based Embankment Design Parameters.} The railway winds from the southeast to the northwest so it is susceptible to the problems led by south-north slope. To improve the embankment stability, positive cooling measures have been implemented in most sections along the CMR (Figure 2(b)). The length of the crushed rock-based embankment reaches $53 \mathrm{~km}$. The crushed rock particle size is mainly from $5 \mathrm{~cm}$ to $30 \mathrm{~cm}$. The crushed rock is primarily composed of moderately weathered schists and gneisses with some pebbles. The crushed rock layer is approximately $1.2 \mathrm{~m}$ in thickness (Figure 2(a)). 


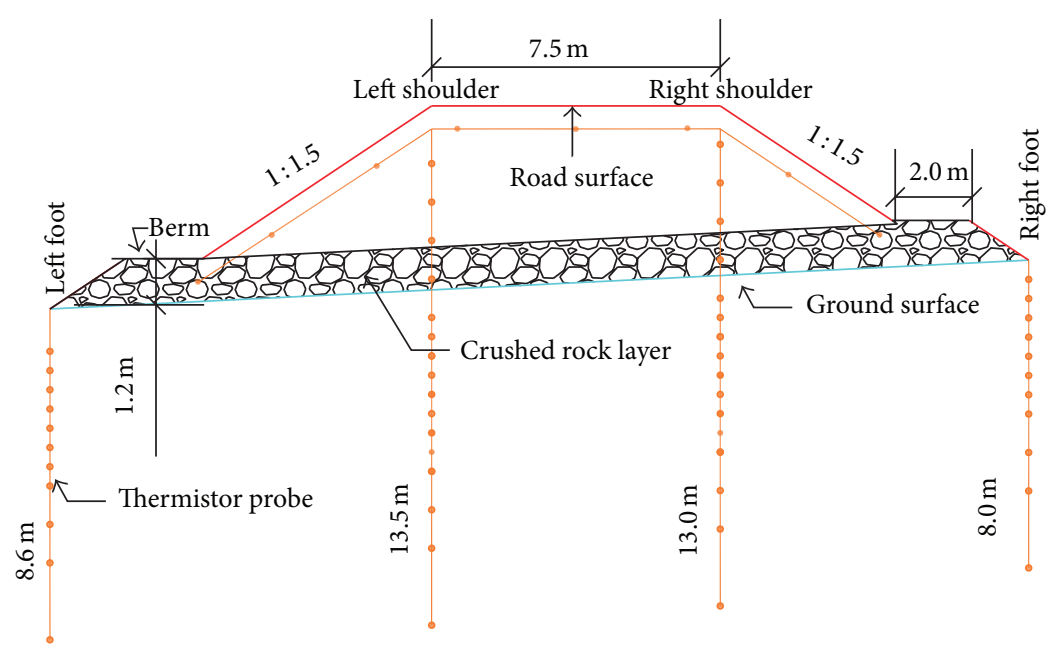

(a)

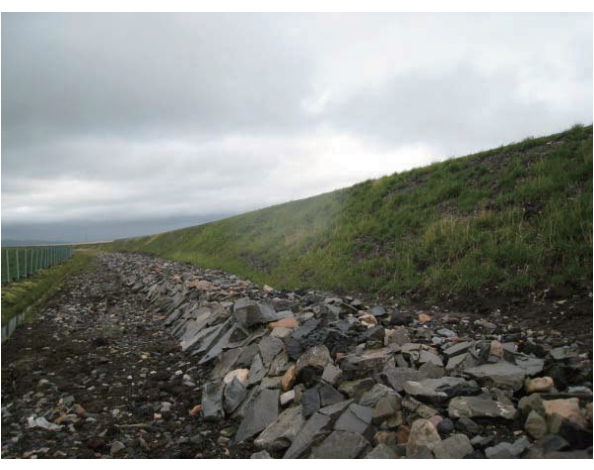

(b)

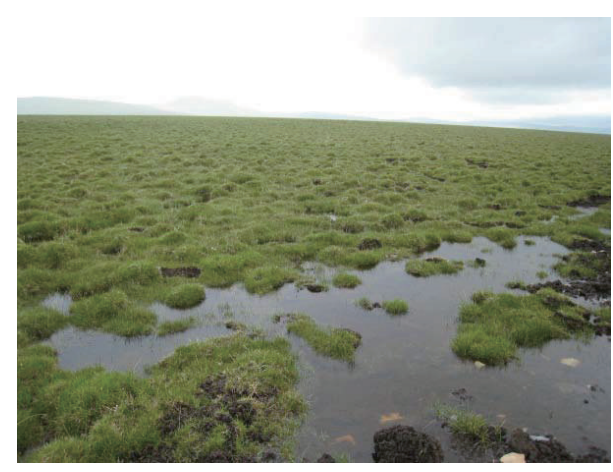

(c)

FIGURE 2: Monitoring sections of the crushed rock-based embankment and berm (unit: $\mathrm{m}$ ). (a) Schematic of the geometric structure and thermistor distribution of the cross section, (b) a picture of the crushed rock-based embankment in section DK40+000, and (c) slope wetland on the left side of DK40+000.

2.3. Monitoring Methods. The construction of monitoring sections of crushed rock-based embankment began in October 2007. The installation of ground temperature probes was not completely finished until July 2008. Among the five sections, only the section of DK74+000 is monitored by the autodata acquisition device, and the all others are monitored by human labor. According to the plan, artificial acquisition sections were stopped when the railway was put into operation in 2010 and the autoacquisition section, DK74+000, is still running today. The data acquisition system consists of thermal-susceptible resistance sensors, a Fluke 187 multimeter with an accuracy of $0.1 \Omega$, and a RTT620k data acquisition device with an accuracy of $0.2 \Omega$. These thermistor probes were manufactured by the State Key Laboratory of Frozen Soil Engineering (SKLFSE). For this system, the measurement range is $\pm 30^{\circ} \mathrm{C}$ and the accuracy is $0.05^{\circ} \mathrm{C}$. The monitoring frequency was set once every 15 days for artificial acquisition sections and 5 days for the autoacquisition section. The embankment shape and positions of the temperature probes in the monitoring sections are shown in Figure 2(a). In this paper, the left slope refers to the sunny slope and the right slope refers to the shady slope.
2.4. Data Processing. Installation of ground temperature probes was completed in December 2007. Excluding the section of DK74+000, the field data in the other sections covered the period from the year 2008 to the year 2009, which involved two freeze-thaw cycles. Apart from the ground temperature, the permafrost table is also used to evaluate the cooling effect of the crushed rock-based embankment. Generally speaking, the maximum $0^{\circ} \mathrm{C}$ isotherm can be regarded as the permafrost table [16]. The linear interpolation method proposed by $\mathrm{Wu}$ and Zhang [17] was used to determine the permafrost table in this study.

\section{Results and Discussions}

3.1. Cooling Effect in Warm Permafrost Regions. Section DK40+000 was constructed in May 2007. The left shoulder hole and the right foot hole were damaged in May 2008. The thermal boundary conditions determine the thermal state of the underlying soil layers to a great extent. When the thawing depth reaches the permafrost table under the embankment, it will trigger thawing in the permafrost and lead to an uneven settlement of the embankment. 


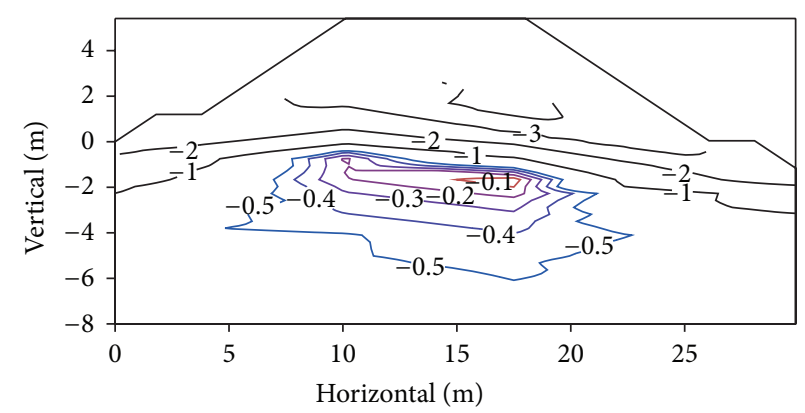

(a)

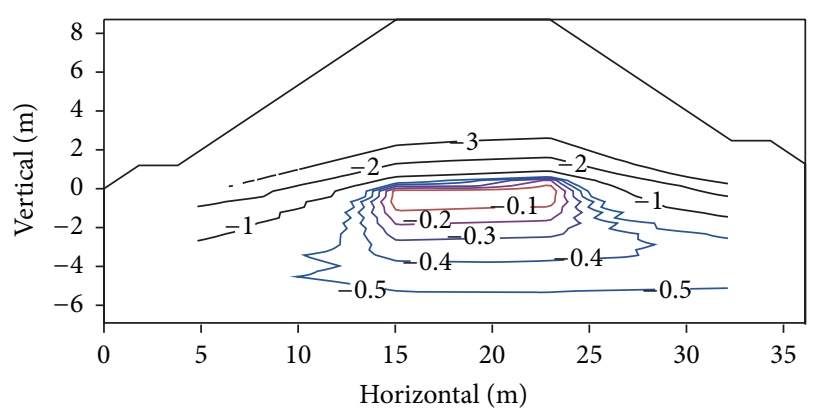

(b)

FIGURE 3: Temperature field of two sections in the warm permafrost region on March 29, 2008 (unit: ${ }^{\circ} \mathrm{C}$ ). (a) DK40+000 and (b) DK74+000.

Figure 3(a) shows the temperature field of section DK40+000 on March 29, 2008. The distribution of the temperature field is asymmetric, extending higher on the left than on the right. For example, the right isotherms are deeper than the left ones, which mean that the cooling effect on the right is much stronger than that on the left.

For embankments higher than $2.5 \mathrm{~m}$, there may often be a thawing core inside the embankment in the first year in warm permafrost regions $[18,19]$. The thawing core weakens the embankment stability considerably. Generally speaking, the topsoil in the permafrost area begins to thaw in the period from April to May on the Qinghai-Tibet Plateau $[20,21]$. Before the thawing season begins, it can be concluded that there is a one-year thawing core if some part inside the embankment is unfrozen. Figure 3(a) displays that temperatures of the embankment and its underlying ground are all below $0^{\circ} \mathrm{C}$. This proves that there is no thawing core in the temperature field of section DK40+000 with an embankment height of more than $3 \mathrm{~m}$. After the first winter, the embankment was fully frozen.

Based on the field data, the ground temperature under the permafrost table increased significantly. For warm permafrost, the asymmetry becomes more obvious with increasing ground temperature. When the thawing depth is deeper than the permafrost table, the asymmetric deformation of the embankment must be taken into account.

Figure $3(\mathrm{~b})$ shows the temperature field of section DK74+000 on March 29 in 2008. Although the temperature field is slightly asymmetric, there is a high temperature permafrost region near the natural ground surface. Moreover, the area of the left slope is larger than that of the right slope, which means that much more solar radiation is absorbed by the sunny slope. As the global air temperature rises, the sunny-shady slope problem becomes more serious, which will likely lead to uneven embankment settlement.

Figure 4 shows the $0^{\circ} \mathrm{C}$ isotherm for the slope foot of sections DK40+000, DK74+000, and DK39+800 from December, 2007, to November, 2009. DK39+800 is a contrast section which is constructed by the use of plain soil. The three sections are all located in the slope wetland, which have similar earth surface and geological conditions. Compared with the crushed rock-based embankment, the only difference of the upper boundaries for ordinary embankment

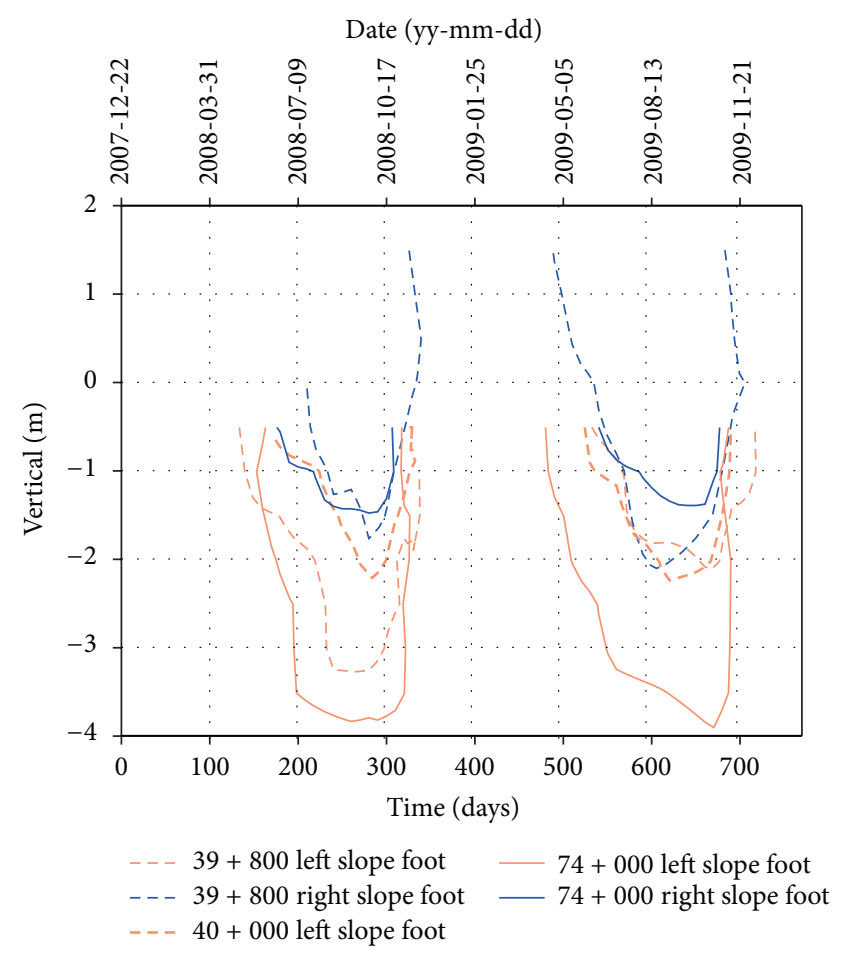

FIGURE 4: Thawing-freezing processes for slope feet of crushed rockbased embankment in warm permafrost regions

exists in the crushed rock berms in the left and right sides. Previous study found that surface temperature of stone may be $2-3^{\circ} \mathrm{C}$ higher than the naked ground surface in the summer [22]. Therefore, the upper boundary temperature of the crushed stone-based embankment is not lower than that of the ordinary embankment.

In a year round, the lowest $0^{\circ} \mathrm{C}$ isotherm represents the permafrost table. The increase of the permafrost table in the slope foot contributes to the formation of longitudinal cracks. In 2008 and 2009, the permafrost table of the right foot in section DK74+000 was shallower than that in section DK39+800. Moreover, the permafrost table of the right foot in section DK74+000 rose by $9 \mathrm{~cm}$ from 2008 to 2009. For the contrast section DK39+800 with plain soil embankment, 
there was a sharp fall of up to $32 \mathrm{~cm}$, even though the right slope is shady and a soil berm was constructed in the left. The change of the permafrost table in the right foot shows that there is natural and forced convection inside the crushed rock berm and embankment, and the crushed rockbased embankment has played a positive role in cooling the underlying permafrost $[15,23,24]$.

The permafrost table of the left slope was disturbed by other local factors other than the crushed rock-based embankment. In 2008, the permafrost table of the left foot in section DK39+800 was shallower than that in section DK74+000 and deeper than that in section DK40+000. In 2009, the permafrost table of the left foot in section DK39+800 was shallower than that in the two other sections. This is in contradiction with the cooling effect of the crushed rock-based embankment in warm permafrost regions. This phenomenon probably results from the following five reasons. Firstly, a pit was excavated in May 2008, which is filled with water due to high rainfall and the runoff from the left upslope. The water pit acts as a thermal reservoir. However, once the thermal state of the water pit becomes stable, it may serve a beneficial role in protecting the permafrost because of its large heat capacity and higher thermal conductivity than the soil in the winter. After one cycle of thawing and freezing, the maximum thaw depth of permafrost decreased by more than $1 \mathrm{~m}$. Secondly, the left foot temperature boreholes of section DK74+000 and section DK40+000 are both outside the embankment, which is affected weakly by the crushed rock-based embankment. Thirdly, the shallow soil is relatively drier in section DK74+000 than in sections DK39+800 and DK40+000, which is not beneficial to the development of permafrost. Fourthly, it is affected by the construction processes. In the end of 2007 , the embankment height was about $5 \mathrm{~m}$. In June, 2008, additional soil layer with $3 \mathrm{~m}$ thick was refilled. Finally, there is a sidewalk used for the construction and maintenance of the railway on the left side of section DK74+000, which disturbed the underlying permafrost.

The evaluation of the cooling effect of crushed rock-based embankment is more persuasive if it is compared with a natural hole. Table 2 lists the permafrost table in sections DK40+000 and DK74+000 from the beginning of 2008 to the end of 2009. During the 2008-2009 freeze-thaw cycle, the permafrost table in the right shoulder and slope foot was close to that in the natural borehole. During the 2009-2010 freezethaw cycle, the permafrost table in the right shoulder was higher than that in the natural borehole. Field data from 2012 to 2014 showed that permafrost table at the right slope foot in section DK74+000 was less than $1 \mathrm{~m}$, which is approximately $0.2 \mathrm{~m}$ shallower than the natural borehole.

Based on the field data of the Northern Datong Mountain and the north bank of the Datong River, the crushed rockbased embankment can raise the permafrost table in the shady side above the natural permafrost table and has little impact on the permafrost table in the sunny slope. It is incapable of eliminating the sunny-shady slope effect in warm and swampy permafrost regions. Additionally, its cooling effect was also disturbed by slope runoff and other factors.
TABle 2: Permafrost table in warm permafrost.

\begin{tabular}{cccc}
\hline \multirow{2}{*}{ Year } & Location & \multicolumn{2}{c}{$\mathrm{PT}(\mathrm{m})$} \\
& $\mathrm{NB} 40+000$ & $\mathrm{Dk74+000}$ \\
\hline \multirow{3}{*}{2008} & LSF & 1.23 & 1.50 \\
& LS & 2.25 & 3.91 \\
& RS & $/$ & $/$ \\
& RSF & 1.25 & $/$ \\
2009 & NB & $/$ & 1.45 \\
\hline \multirow{3}{*}{} & LSF & 1.40 & 1.23 \\
& LS & 2.20 & 3.93 \\
& RS & $/$ & $/$ \\
& RSF & 0.94 & 1.40 \\
\hline
\end{tabular}

Notes: NB: natural borehole, LSF: left slope foot, LS: left shoulder, RS: right shoulder, RSF: right slope foot, and PT: permafrost table.

3.2. Cooling Effect in Cold Permafrost Regions. Figure 5 shows the temperature field of section DK94+900 on August 28 in 2008 and on August 30 in 2009. The temperature fields are symmetric in the first year and the second year, which may be related to nearly south-north strike. The vertical coordinates of $0^{\circ} \mathrm{C}$ isotherm of left slope foot, embankment center, and right slope foot are $-1.40 \mathrm{~m},-0.30 \mathrm{~m}$, and $-0.93 \mathrm{~m}$ in Figure $5(\mathrm{a})$ and $-1.50 \mathrm{~m},-0.32 \mathrm{~m}$, and $-0.63 \mathrm{~m}$ in Figure 5(b), which indicates that the $0^{\circ} \mathrm{C}$ isotherms increase in the left foot, decrease in the right foot, remain stable in the center. The thawing depth often penetrates the permafrost table in mid-September [20]. Although the $0^{\circ} \mathrm{C}$ isotherms in the end of August are not the maximal thawing depth, the trends of them are the same. The trends of $0^{\circ} \mathrm{C}$ isotherms may result from air temperature changes and other reasons, which all cannot demonstrate the cooling effect of the crushed rockbased embankment.

Under the original permafrost table, temperature isotherms look like concave shape, such as $-0.5^{\circ} \mathrm{C}$ and $-1.0^{\circ} \mathrm{C}$, which mean that the ground temperature rises continuously from the slope foot to the embankment center. In contrast with Figure $5(\mathrm{a})$, the $-0.5^{\circ} \mathrm{C}$ and $-1.0^{\circ} \mathrm{C}$ isotherms in Figure 5(b) move downward, which indicate that the soil below the embankment became warmer than before.

The above analysis shows that temperature field of section DK94+900 at specific dates in the first two years cannot reflect the cooling effect of crushed rock-based embankment. Table 3 lists the permafrost tables of different boreholes in the DK94+900 section and the two contrast sections DK94+340 and DK94+660. Due to construction disturbance in 2007, the permafrost tables exhibit different behaviors compared to the other boreholes of DK94+900. However, through a comparison with sections DK94+340 and DK94+660 without crushed rock-based embankment, it can be found that the permafrost tables in the same position in the experiment section are all lower than those in the contrast section. The differences in the permafrost table between the crushed rockbased and plain soil embankments varied from $0.25 \mathrm{~m}$ to $1.50 \mathrm{~m}$.

Sections DK123+150 and DK123+250 were located on the north bank of the Duosuoqu river. The landform of 


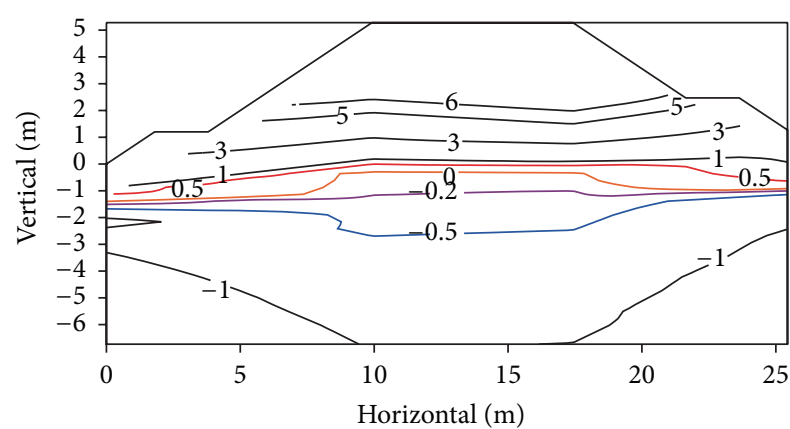

(a)

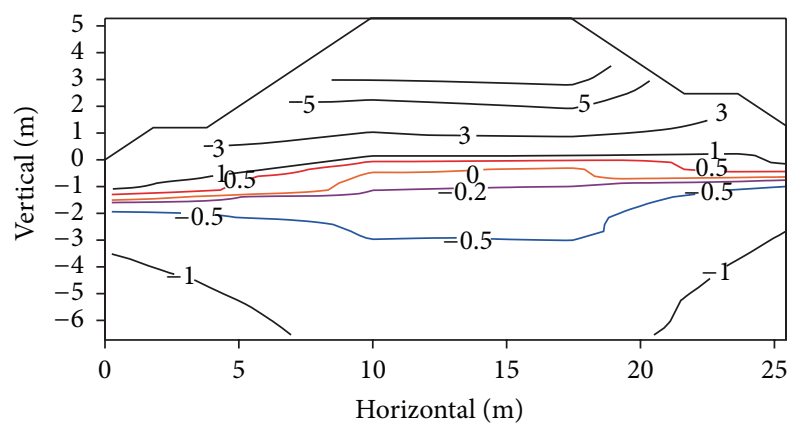

(b)

Figure 5: Temperature field of section DK94+900 at specific dates (unit: ${ }^{\circ} \mathrm{C}$ ). (a) 2008-08-28 and (b) 2009-08-30.

TABLE 3: Permafrost table in section DK94+900 and contrast sections.

\begin{tabular}{lcccccc}
\hline \multirow{2}{*}{ Time } & \multirow{2}{*}{ Location } & \multicolumn{5}{c}{ PT (m) } \\
& & NB & LSF & LS & RS & RSF \\
\hline \multirow{2}{*}{2008} & Dk94+340 & 1.48 & 2.37 & 2.39 & 3.00 & 2.78 \\
& Dk94+660 & 1.85 & 2.27 & 2.29 & 2.72 & 2.44 \\
& Dk94+900 & 1.45 & 1.72 & 1.28 & 1.50 & 2.19 \\
\hline \multirow{3}{*}{2009} & Dk94+340 & 1.79 & 3.39 & 2.40 & 2.75 & 2.55 \\
& Dk94+660 & 1.92 & 2.10 & 2.33 & 2.78 & 2.51 \\
& Dk94+900 & 2.15 & $/$ & 1.52 & 1.51 & 1.89 \\
\hline
\end{tabular}

the site had a concave shape. Figure 6 shows the temperature field of section DK123+150 on October 20, 2009. Compared to sections DK40+000, DK74+000, and DK94+900, the temperature field is very asymmetric. From the left slope foot to the right slope foot, $0^{\circ} \mathrm{C}$ isotherm increased continuously. The permafrost table in the left slope foot is approximately $2.0 \mathrm{~m}$ deeper than that in the right slope foot (Table 4). Inside the embankment, a high temperature core developed in the left upper portion, which is under the left shoulder (Figure 6). In general, because of the large solar radiation area and the disturbance caused by the left sidewalk, the ground temperature in the left side is much higher than that in the right side.

Owing to the disturbance of the left sidewalk, the initial embankment construction, and the slope orientation, the permafrost tables also rise continuously from the left foot to the right foot (Table 4). The permafrost table is a little deeper

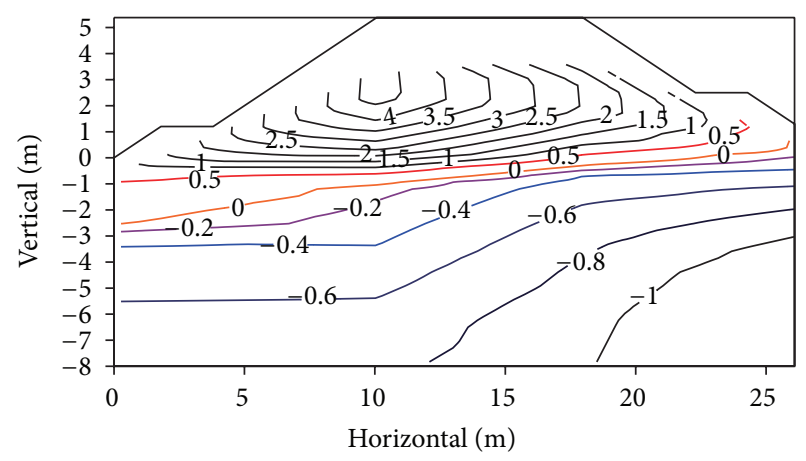

FIGURE 6: Temperature field of the maximum thaw depth in section DK123+150 (unit: ${ }^{\circ} \mathrm{C}$ )

TABLE 4: Permafrost tables of sections DK123+150 and DK123+250.

\begin{tabular}{lcccc}
\hline \multirow{2}{*}{ Section } & \multirow{2}{*}{ Location } & \multicolumn{2}{c}{ PT (m) } & \multirow{2}{*}{ Increment (m) } \\
\hline \multirow{5}{*}{ DK123+150 } & NB & 1.41 & 1.26 & -0.15 \\
& LSF & 2.90 & 2.80 & -0.10 \\
& LS & 1.54 & 1.55 & 0.01 \\
& RS & 1.35 & 1.15 & -0.20 \\
& RSF & 0.98 & 0.98 & 0.00 \\
\hline \multirow{5}{*}{ DK123+250 } & NB & 0.98 & 0.85 & -0.13 \\
& LSF & 1.64 & 2.15 & 0.51 \\
& LS & 1.43 & 1.53 & 0.10 \\
& RS & 0.77 & 0.77 & 0.00 \\
& RSF & 1.72 & 1.32 & -0.40 \\
\hline
\end{tabular}

than the natural borehole at the left shoulder and shallower at the right shoulder. From 2008 to 2009, the permafrost tables of the natural borehole rose, but the permafrost tables under the embankment behaved differently. In section DK123+150, the permafrost tables at the left slope foot and right shoulder increased by approximately $0.1-0.2 \mathrm{~m}$. In section DK123+250, the permafrost table rose by $0.4 \mathrm{~m}$ only at the right slope foot. The permafrost tables at the other boreholes almost declined. For the left slope foot, it descended by approximately $0.51 \mathrm{~m}$.

The crushed rock-based embankment can cool down the entire permafrost compared with plain soil embankment. However, its cooling effect on the south-facing side of the embankment is not clear. The permafrost tables in the sunny slope foot and shoulder are almost deeper than the natural borehole.

3.3. Effect of Slope Wetland on the Temperature Field of Crushed Rock-Based Embankment. The past studies showed that the permafrost tables beneath the crushed rock-based embankment can be raised by as much as between $1.8 \mathrm{~m}$ and $2.6 \mathrm{~m}$ at most sites [7]. Only in some warm permafrost area, the ground temperature near the permafrost table did not show the clear cooling effect [15]. The conclusions in this paper are in agreement with the previous ones in the warm permafrost area. Degradation of permafrost in cold permafrost along the CMR may be affected mainly by the 


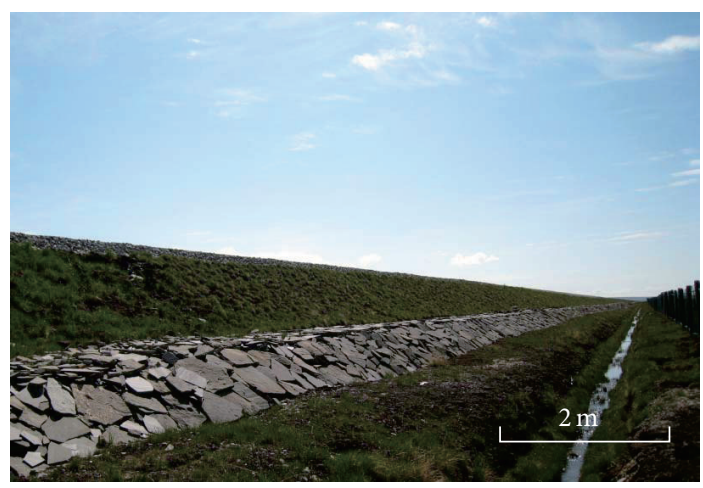

(a)

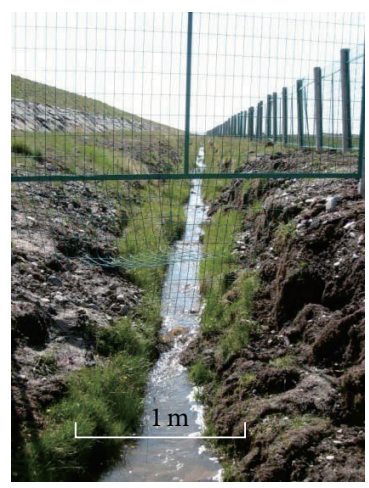

(b)

Figure 7: Ditch near the embankment along the CMR: (a) distant view of drainage ditch, (b) close shot of water outlet, which is adjacent to the culvert.

slope wetland. In the slope wetland, there is often ground surface water and suprapermafrost water in the summer, which flow downward on the surface or in the active layer. Previous studies have confirmed that the wetland could help cool down the topsoil and promote the development of permafrost [25]. In warm permafrost regions, permafrost islands often occur in the wetland [26, 27].

Before embankment construction in the slope wetland, runoff on the surface and in the active layer is often slow and uniform. After construction, the embankment acts like a dam, which alters the water flow path and quantity. On the uphill side, water will flow longitudinally along the foot. The water velocity and flow quantity is far higher than the natural state. Occasionally, there is always flow water in the ditch near the foot of embankment slope in the summer (Figure 7). Lv et al. [25] pointed out that the seasonal river can heat the permafrost and increase the maximum thawing depth. Section DK123+250 is located at the center of a concave geomorphic unit, where the elevation is the lowest. Before embankment construction, the water content of topsoil was $120.9 \%$. After the embankment was completed, the water content of the topsoil on the right slope foot increased sharply because the water on the ground surface and in the active layer was obstructed on the right uphill side of the embankment. Once the soil was over saturated, the water flowed downward along the right slope foot (Figure 7). The thermal erosion of flow water led to a permafrost table at the right foot of section DK123+250 that is deeper than the natural borehole (Table 4). In the neighboring DK123+150 section, the topsoil water content was only $45.5 \%$ after the embankment was built because of its higher elevation and initially drier surface soil. The water flow was very weak and its thermal erosion can be neglected. Therefore, the permafrost table in the right foot of section DK123+150 was much lower than the natural borehole (Table 4).

On the downhill side, the water was obstructed by the embankment and only a little water can penetrate through it. Therefore, the topsoil began to dry and permafrost degradation occurs. Taking the example of section DK94+900 and its contrast sections, the permafrost tables at the left shoulder and left slope foot are all deeper than the natural borehole (Table 3).

\section{Conclusions}

(1) The cooling effect of crushed rock-based embankment on slope wetland is closely related to MAGT of permafrost. In the warm permafrost region, only the shady side can be better cooled for the crushed rockbased embankment. In the cold permafrost region, temperatures of the entire embankment would fall down. This engineering measure cannot eliminate the problems led by south-north slope in the warm and cold permafrost region.

(2) Slope wetlands can influence the temperature field in the crushed rock-based embankment. On the uphill side of the embankment, it can lead to the degradation in some cases and the development of permafrost in the other cases. The final effect depends on the conditions of topsoil water content and earth surface runoff. On the downhill side, it always helps warm the permafrost.

In the long term, there is a need for other stronger measures to reduce the sunny-shady slope effect. Moreover, the influence of drainage, the sunny-shady slope phenomenon, geological environment, and other local factors on the cooling effect of the crushed rock-based embankment must not be neglected.

\section{Conflict of Interests}

The authors declare that there is no conflict of interests regarding the publication of this paper.

\section{Acknowledgments}

This work was financially supported by the National Basic Research Program of China (973 Program, Grant no. 2013CBA01803), the National Natural Science Foundation of 
China (Grant no. 41101065), and CAS "Light of West China" Program (Grant no. 29Y229D01) to Chen Ji.

\section{References}

[1] J. W. Rooney, "Rock fill embankment applications for convective foundation cooling on the RAM Railway system," in Proceedings of the 5th International Symposium on Cold Region Development, pp. 399-402, Anchorage, Alaska, USA, May 1997.

[2] K. T. Cheng, P. L. Tung, and H. B. Lo, "Experimental research on an area with massive ground ice at the lower limit of alpine permafrost," in Proceedings of the 3rd International Conference on Permafrost, pp. 199-222, National Research Council of Canada, 1978.

[3] G. D. Cheng, B. L. Tong, and X. B. Luo, "Two problems in the construction of embankment with thick ground ice," Journal of Glaciology and Geocryology, vol. 3, no. 2, pp. 6-12, 1981.

[4] Y. Hairong, "The roadbed stability in permafrost region," Journal of Glaciology and Geocryology, vol. 7, no. 1, pp. 83-88, 1985.

[5] G. S. He, J. K. Ding, and Y. Q. Li, "10 Thermal properties of crushed stones and its application," Journal of Glaciology and Geocryology, vol. 22, supplement, pp. 33-37, 2000.

[6] W. Ma, G. D. Cheng, and Q. B. Wu, "Preliminary study on technology of cooling foundation in permafrost regions," Journal of Glaciology and Geocryology, vol. 24, no. 5, pp. 579587, 2002.

[7] G. Cheng, Q. Wu, and W. Ma, "Innovative designs of permafrost roadbed for the Qinghai-Tibet Railway," Science in China, Series E: Technological Sciences, vol. 52, no. 2, pp. 530-538, 2009.

[8] J. Chen, Z. Feng, S. Yu et al., "Permafrost along National Highway 214 and its engineering geological condition evaluation," Journal of Glacioloby and Geocryology, vol. 36, no. 4, pp. 790801, 2014.

[9] D. J. Goering and P. Kumar, "Winter-time convection in opengraded embankments," Cold Regions Science and Technology, vol. 24, no. 1, pp. 57-74, 1996.

[10] D. J. Goering, "Experimental investigation of air convection embankments for permafrost-resistant roadway design," in Proceedings of the 7th International Conference on Permafrost, Yellowknife Press, Quebec City, Canada, June 1998.

[11] D. J. Goering, A. Instanes, and S. Knudsen, "Convective heat transfer in embankment ballast," in Ground Freezing 2000, Balkema, Rotterdam, The Netherlands, 2000.

[12] D. J. Goering, "Passively cooled railway embankments for use in permafrost areas," Journal of Cold Regions Engineering, vol. 17, no. 3, pp. 119-133, 2003.

[13] Y. M. Lai, L. X. Zhang, S. J. Zhang, and L. Mi, "Cooling effect of ripped-stone embankments on Qing-Tibet railway under climatic warming," Chinese Science Bulletin, vol. 48, no. 6, pp. 598-604, 2003.

[14] Q.-B. Wu, S.-Y. Zhao, W. Ma, Y.-Z. Liu, and L.-X. Zhang, "Monitoring and analysis of cooling effect of block-stone embankment for Qinghai-Tibet Railway," Chinese Journal of Geotechnical Engineering, vol. 27, no. 12, pp. 1386-1390, 2005.

[15] Q. B. Wu, X. F. Dong, and G. L. Jiang, "Cooling effect differences of soil beneath open and closed block-stone embankments," Chinese Journal of Rock Mechanics and Engineering, vol. 25, no. 12, pp. 2565-2571, 2006.

[16] C. R. Burn, "The active layer: two contrasting definitions," Permafrost Periglacial Process, vol. 9, pp. 411-466, 1998.
[17] Q. B. Wu and T. Zhang, "Changes in active layer thickness over the Qinghai-Tibetan plateau from 1995-2007," Journal of Geophysical Research, vol. 115, Article ID D09107, 2010.

[18] L. X. Zhang, S. S. Yuan, and Y. P. Yang, "Mechanism and prevention of deformation cracks of embankments in the permafrost region along Qinghai-Xizang Railway," Quaternary Sciences, vol. 23, no. 6, pp. 604-610, 2003.

[19] J. B. Chen, S. J. Wang, J. Z. Zhang, and W. Ma, "Formation and mechanism of high embankment diseases of QinghaiTibet highway," Journal of Chang'an University (Natural Science Edition), vol. 28, no. 6, pp. 30-35, 2008.

[20] L. Zhao, G. Cheng, S. Li, X. Zhao, and S. Wang, "Freezing and thawing processes of active layers in Wudaoliang, QinghaiTibet Plateau," Chinese Science Bulletin, vol. 45, no. 11, pp. 12041211, 2000.

[21] K. Xia, Y. Luo, and W. P. Li, "Simulation of freezing and melting of soil on the Northeast Tibetan Plateau," Chinese Science Bulletin, vol. 56, no. 22, pp. 1828-1838, 2011.

[22] P. Mao, "Regulating effect of urban grassland on climatic environment in Qinhuangdao," Journal of Environmental Management College of China, vol. 20, no. 4, pp. 43-45, 2010.

[23] Y. Lai, M. Zhang, W. Yu et al., "Experimental study on the cooling effect and mechanism of closed ripped-rock embankment," Journal of Glaciology and Geocryology, vol. 26, no. 5, pp. 576581, 2004.

[24] J. Qian, Q.-H. Yu, W. Gu, and Y.-H. You, "Experimental study of relation between convection process and temperature characteristics of block-stone layer," Rock and Soil Mechanics, vol. 33, no. 1, pp. 83-88, 2012.

[25] L. Z. Lv, H. J. Jin, S. L. Wang, X. Xue, R. X. He, and S. P. Yv, "Dual influences of local environmental variables on ground temperatures on the Interior-Eastern Qinghai-Tibet Plateau (II): sand-layer and surface water bodies," Journal of Glaciology and Geocryology, vol. 30, no. 4, pp. 546-555, 2008.

[26] H. J. Jin, Q. H. Yu, L. Z. Lv et al., "Degradation of permafrost in the Xing'anling Mountains, Northeastern China," Permafrost and Periglacial Processes, vol. 18, no. 3, pp. 245-258, 2007.

[27] H. J. Jun, G. Y. Sun, S. P. Yu, R. Jin, and J. He, "Symbiosis of marshes and permafrost in Da and Xiao Hinggan Mountains in Northeastern China," Chinese Geographical Science, vol. 18, no. 1, pp. 62-69, 2008. 

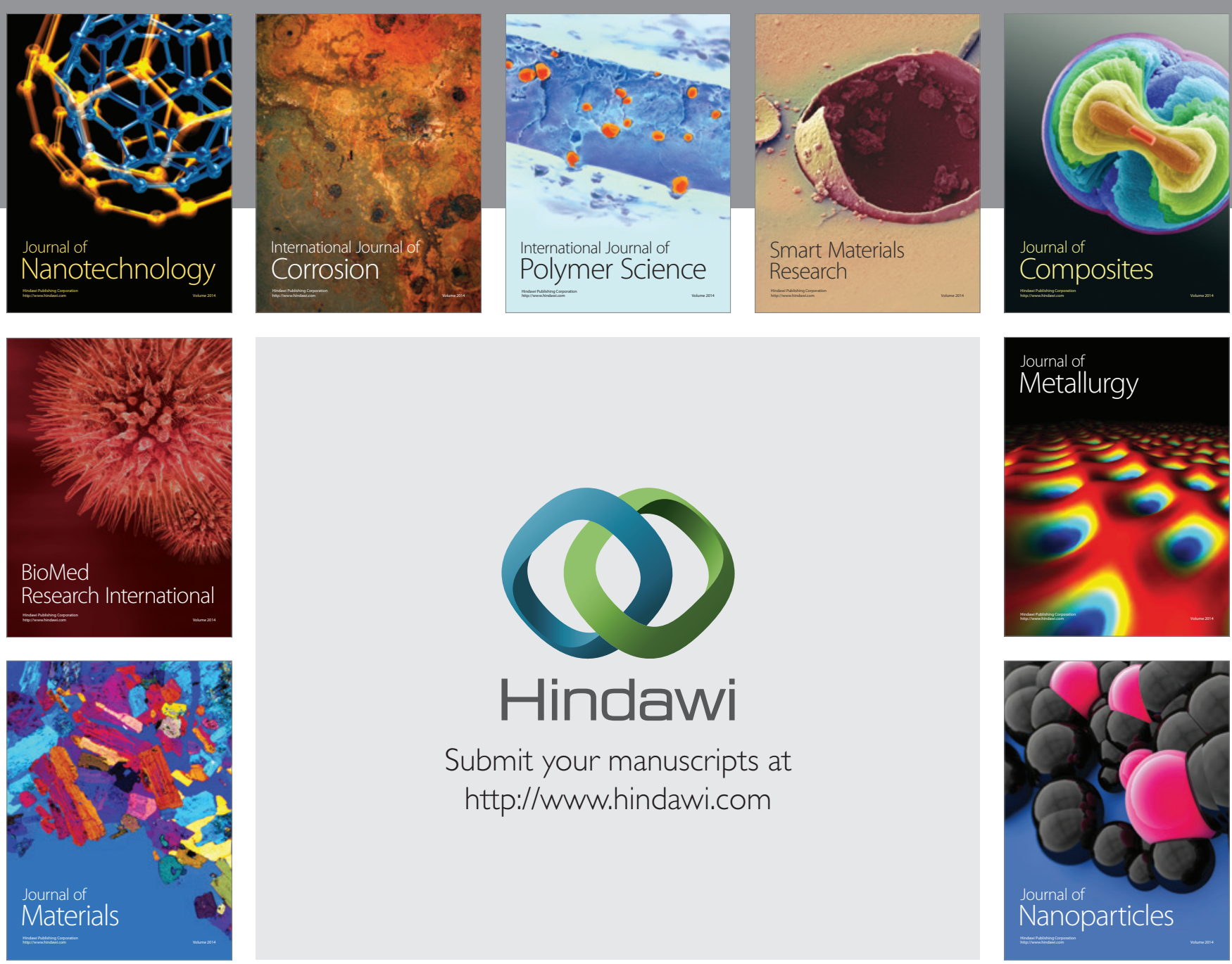

Submit your manuscripts at http://www.hindawi.com
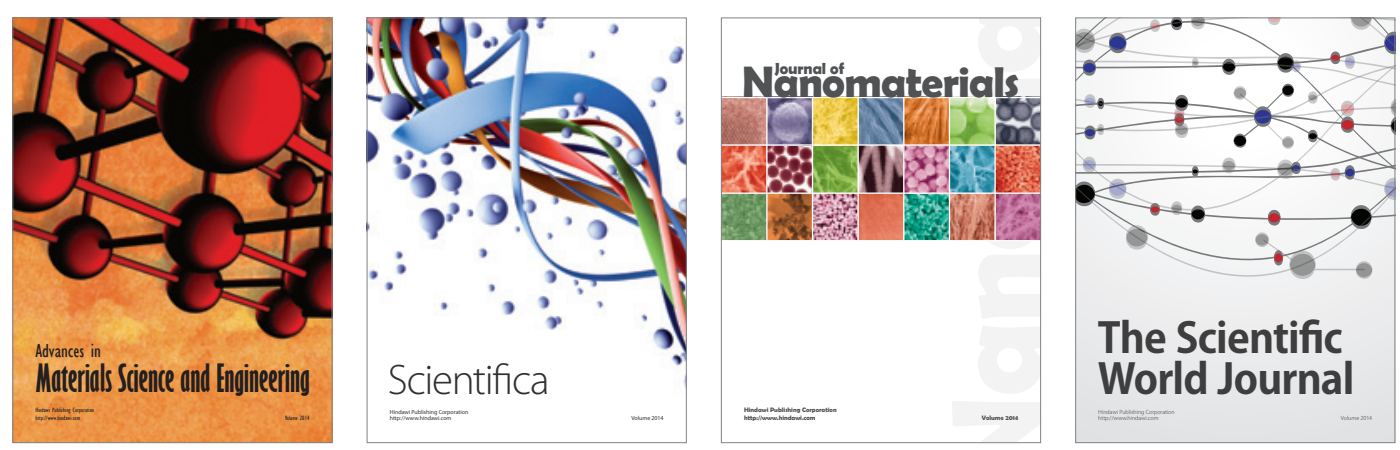

\section{The Scientific World Journal}
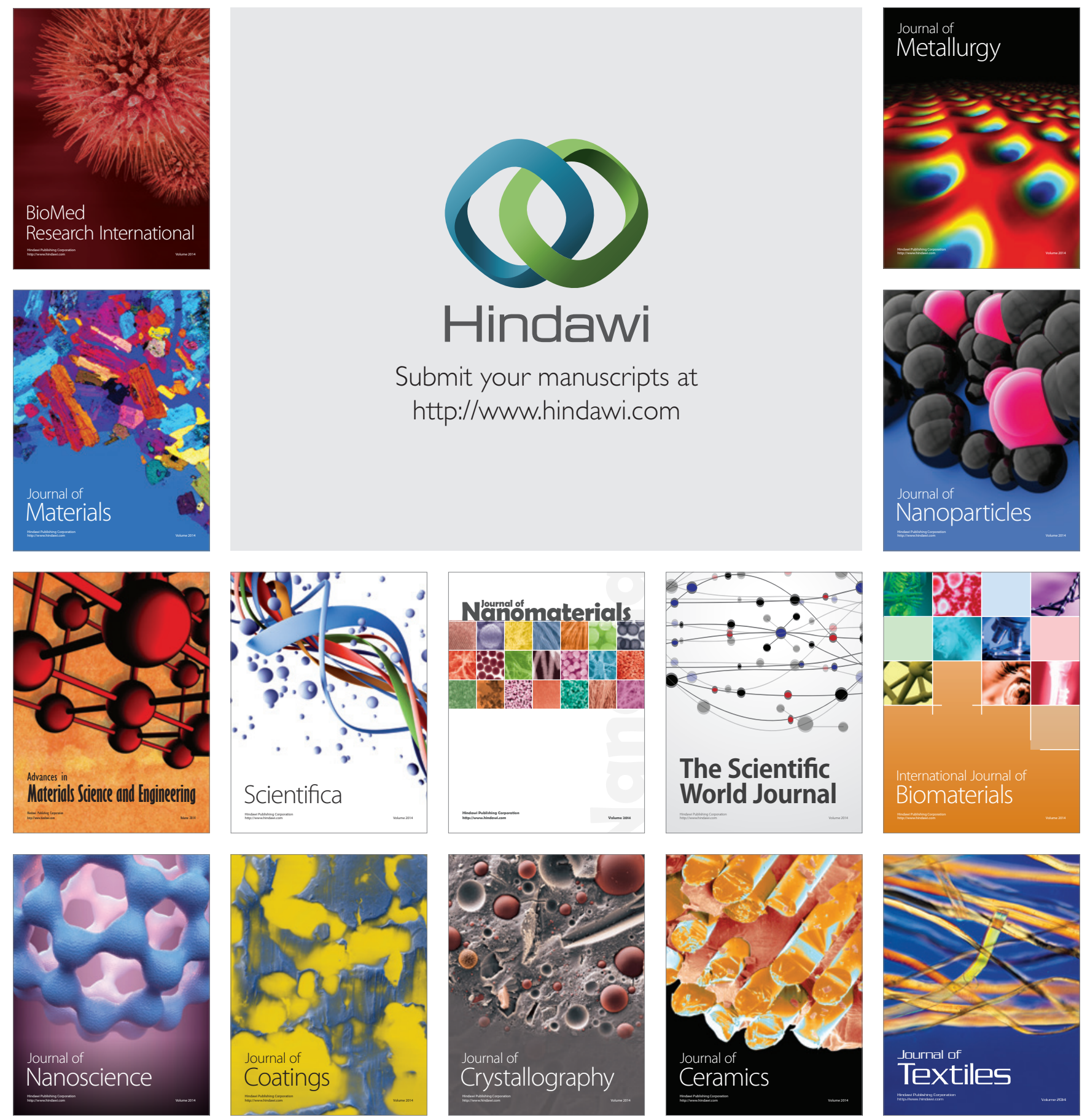